\title{
Isolating Deoxyribo Nucleid Acid (DNA) as The Basic for Inquiry Learning to Improve Science Process Skill (SPS)
}

\author{
Mia Nurkanti ${ }^{1}$ \\ \{mia.nurkanti@unpas.ac.id $\left.{ }^{1}\right\}$ \\ Departement of Education biology, Pasundan University J1. Tamansari no 6-8 Bandung Indonesia ${ }^{1}$,
}

\begin{abstract}
This study aims to determine the ability of students in inquiry learning to improve students' scientific process skills. This research involves $7^{\text {th }}$ semester students of a university in Bandung who took biotechnology course with concentration on DNA isolation in 2016. The research method used in this research is experimental with observation sheets, questionnaires, and tests were used as data collection instruments. From both the control class and the experimental class, significant difference of in terms of students' scientific skills are identified.The observation sheet shows the difference of the student's knowledge level which has the average value of $31,97 \%$, the result of student questionnaire is $18,65 \%$, and result. Aspects of the process of scientific processes that assess the ability to make observations, application of concepts, experimental design, interpretation, prediction, questioning, formulation of hypotheses, experiments, use of tools, application of concepts and communicate with some students who still have trouble laboratory practicum. Further research should be developed and conducted on students from different study programs.
\end{abstract}

Keywords: Inquiry, science process skills, DNA isolation.

\section{Introduction}

Since the 21st century begins science has undergone many developments including the field of biological sciences. The focus of biological studies has changed significantly, not only limited to the level of organisms or cells, but deeper to the focus of the present study already includes at the molecular level or so-called molecular biology [1]. The study of molecular biology developed also quite rapidly beginning with the discovery of the chemical structure of DNA by Watson and Crick. Product development of molecular biology is the basis for the development of modern biology [2].

One study of molecular biology the genetically engineered matter is DNA isolation. DNA isolation is an important stage in molecular-based activity. According to (Ranjan, Kishore, Jadon, Bhatt, \& Gupta, 2010), it appears that the content may inhibit various processes from cutting DNA, amplification, to cloning [3]. Good-quality DNA is useful for further use such as the use of molecular markers, the creation of genomic libraries, and DNA sequencing. 
Teaching and learning process has long put its emphasis on teachers rather than students. It may also seem to be true in biology as (Rustaman, 2005) suggested; in that the knowledge gained by students has been delivered in various ways so that people are more fixated on science products than on the scientific process and attitude involved in the development of the product [4]. Such paradigm may create further problems as many subjects in biology require students to emphasize more on the process rather than the end product. One of the subjects in which such emphasis is essential is DNA isolation.

The study of genetic engineering related to the concept of DNA isolation should use some learning methods in the delivery of material to the students because the complexity of genetic engineering learning is in line with $21^{\text {st }}$-century learning when viewed from technological advances and guiding vision. The teaching methods presented to support learning are supported by the statement of the National Science Foundation (1995) in journal (Hariyadi, 2015) that warn against the enormous challenges to biological science as it enters the $21^{\text {st }}$ century to understand the biological system in all its complexities while preserving and utilizing sustainable biological systems [2].

In fact, genetics learning processes or genetic are particularly passive in nature and most students give little or even questions [5]. The learning process tends to be one-way, because all the genetic engineering material delivered by lecturers is more accepted by the students without knowing the student understands the material or not.

The concept of DNA isolation, however, is a concept that is relatively difficult to teach if it is only delivered through conventional teaching and learning methods, which generally put more emphasis on the end products rather than on scientific process and attitude. In fact, the knowledge and skills acquired by students are expected not to be the result of remembering a set of facts but a process of self-discovery.

One learning method which might be appropriate to encourage self-process discovery is inquiry. Inquiry is one of the learning processes that sets the role of students in a lesson as a priority by enabling them to ask questions, find information and conduct an investigation. It enables students to develop their intellectual abilities associated with reflective thinking processes.

In an attempt to shift teaching and learning paradigm from product-oriented to processoriented, this study attempts to investigate the effectiveness of inquiry in developing students' mastery of scientific process and the development of scientific attitude within students through DNA isolation

Based on the complaints and facts that occur in the teaching process, the lecturers have more difficulty in conducting a comprehensive evaluation, especially in assessing the process skills that students get immersed in the process of learning genetic engineering, the lecturer decided to start learning genetic engineering by using a practicum conducted on sub-concepts DNA isolation. The practice is expected to assess students' science process skills in understanding the general engineering concept as well as the concept of DNA isolation in particular through basic inquiry learning to assess the skills of the individual science process as a whole. 


\section{Research Methodology}

This study employed quasi experiment with one case study design in investigating students' learning processes in isolating DNA. It involved 150 prospective teachers $-7^{\text {th }}$ semester students registered in biology education program-who were enrolled in the biotechnology course in the 2015-2016 academic year at a teacher training institute (LPTK) in Bandung. They were divided into 4 classes; classes A, B and C as the experimental groups and class D as the control group. Samples were taken randomly from all classes. The learning processes observed included students' observation, concept implementation, experimental design, tool use, and planning experiments. The data is then measured through observation sheets, questionnaires, and interviews, and is supported by test results that are compiled based on several indicators of scientific process skills.

Observation sheets are used when learning the process of practising DNA isolation in a biological laboratory. The observation sheets were used to observe some aspects of the science process skills that students had during the practicum work and to assess the practicum document in the form of the DNA isolation report that has been done. Assessment of the aspects of the process of science is carried out to the four classes of practice, the first class is a control class given the usual practicum learning without the giving of inquiry activities provided by the practicum lecturer, while the other three classes are classes of practicum given by the process of inquiry learning so that it can be known aspects of process skills the science obtained from the four classes.

The following is the description of the process of DNA isolation. The first step in isolating DNA was by combining the fruit as a DNA source to break the cell membrane and the nuclear membrane mechanically. The next step was to filter the fruit mixture and insert the extract into the detergent and salt solution. Salt has the same function as SDS in DNA isolation in the white blood cell genome. This provides an ionic condition for a more stable reaction [6]. The solution was stirred so as not to produce bubbles. It was also to promote larger cell particles and detergent movements for a faster reaction because detergents can break cell membranes.

After that, a solution of fruit extract, detergent and salt were inserted into the test tube, given a drop of cold alcohol to produce a white ring between the mixture and alcohol.

\section{Results And Discussion}

\subsection{Result}

The research shows that the application of inquiry learning to develop science process skills can improve aspects of scientific process skills such as observation ability, concept implementation, experimental design, predictions, make some questions, create hypothesis formulations, conduct experiments, find out how to use practicum tools, and apply and communicate a concept.

\subsubsection{Result of Observation Sheet}

Observation sheets were used when learning the process of practicing DNA isolation in a biological laboratory. The observation sheets were used to observe some aspects of the science 
process skills that students carried out during the practicum work and to assess the practicum document in the form of the DNA isolation report that had been done. Assessment of the aspects of the process of science was then carried out to the four classes of practice. The first class is a control class given the usual practicum learning without the giving of inquiry activities provided by the practicum lecturer, while the other three classes are classes of practicum given by the process of inquiry learning so that it can be known aspects of process skills the science obtained from the four classes, then the third class of experiments obtained the average data results calculated per aspect of the science process skills as seen in the chart below.

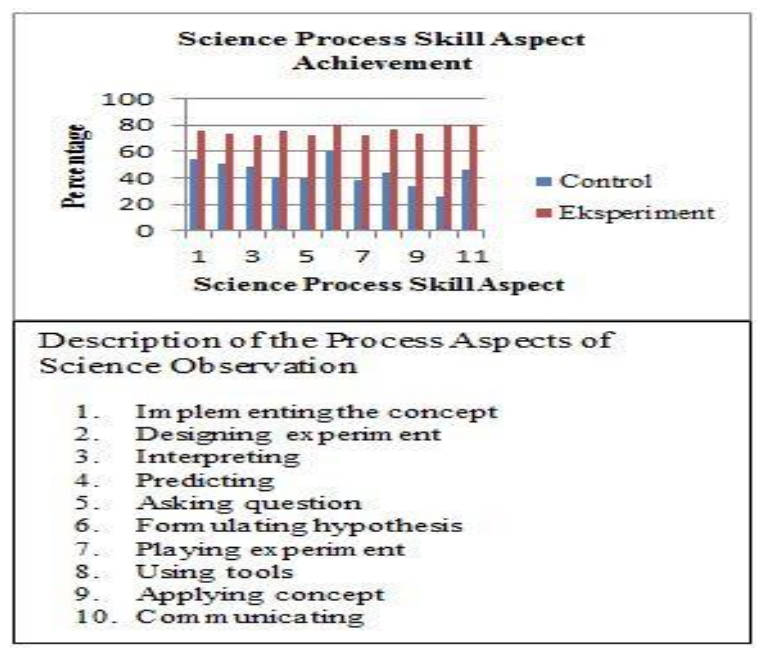

Fig. 1. Graph of Percentage of achievement of science process skill aspect based on result of observation sheet

The chart shows the increase in average achievement of $31.97 \%$. Yet, the scores of control class without inquiry learning is regarded to be relatively low in the scientific process skills. The highest score is the aspect of selection of practicum questions with a value of $59.50 \%$ while the lowest score aspects of the science process skill without inquiry learning are the aspect of applying the concept. The experimental group, however, in the learning given inquiry tends to have higher score in the aspects of science process skills $(>70 \%)$. The highest value of scientific process skill is the inquiring aspect of $80,50 \%$ practice question, while the lowest aspect of science process skill is a hypotesis aspect which is $72,40 \%$. The result of control class observation without inquiry learning act has. The highest score of control class without inquiry learning is an aspect of selection of practicum questions with $59.50 \%$ value whereas. But in the learning given inquiry itself has a high level of the process has a high $(<70 \%)$. The highest value associated with that practicum. $80,50 \%$, while aspect. The result of observation in the class that is not determined by the inquiry learning of the low teaching practice still depends on the practicum given by the teacher so that the practicum activity tends to be passive so that the practicum study is in accordance with what has been completed since the beginning without any active activity from all students who do the lab at the beginning the classes given inquiry study have a high value in the field of process knowledge, because in 
that class the teacher can form the knowledge already possessed by the student in doing the practicum.

\subsubsection{The Result of Science Skills Process Skills}

Questionnaires are filled by all four class students based on students' perspective on the attainment of inquiry-based learning. The students' science process skills according to the questionnaire in both the control class and the experimental class showed an increase among the four classes. the average increase in the value of aspects of the science process skills seen from the control class with the experimental class according to the questionnaire obtained is worth $18.65 \%$. Details of increasing aspects of the science process skills can be seen in the graph:

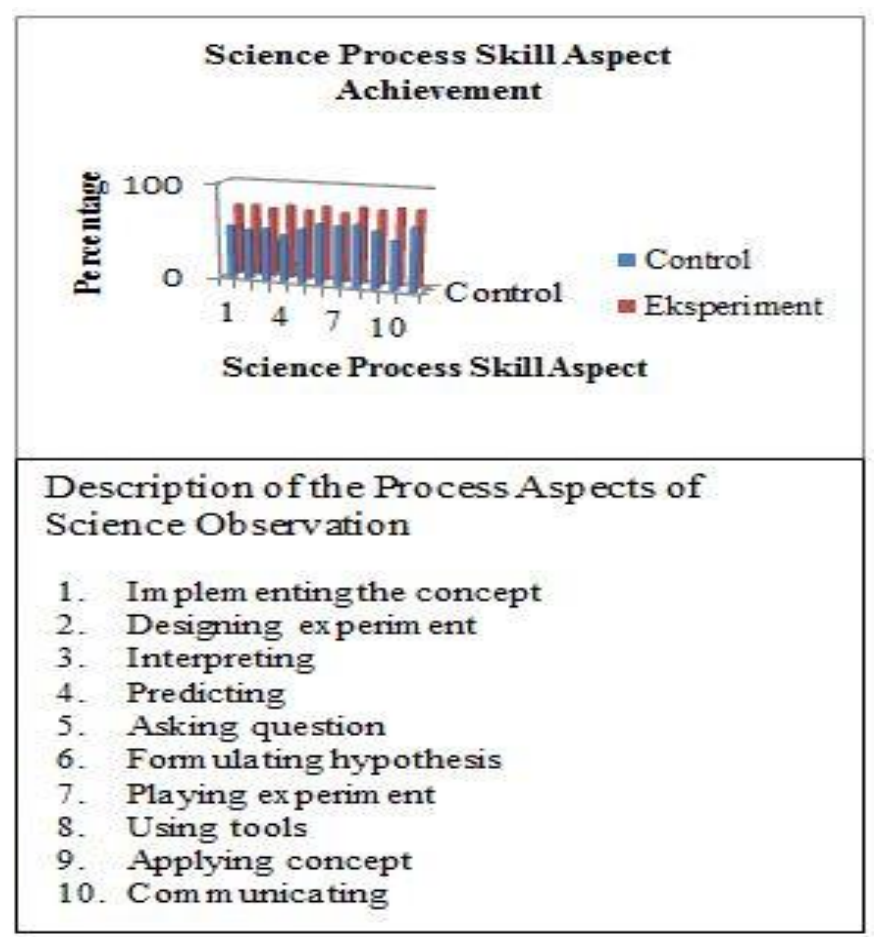

Fig. 2. Graph Percentage of achievement of science process skill aspect based on result of questionnaire 


\subsubsection{The Result of Science Skills Process Skills}

Science process skill test is used only as supporting data to know the improvement of learning outcomes based on inquiry in improving aspects of students' science process skill. This test is done at the end of the lesson. Details of student test results to see aspects of the science process skills can be seen as follows:

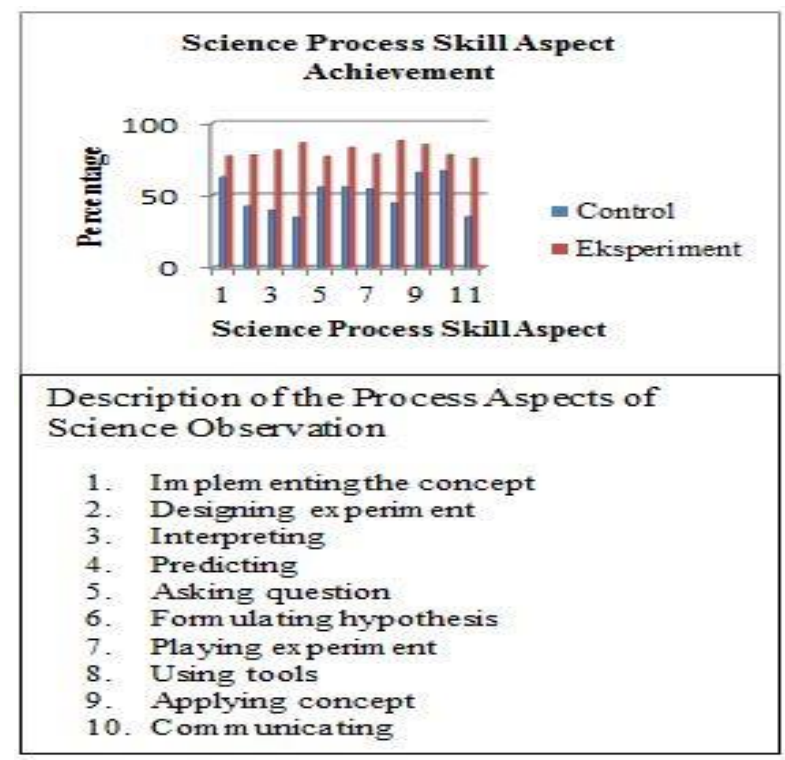

Fig. 3. The percentage of achievement of science process skill aspect based on student test result

From the graph, it can be seen that the average difference of student test between the control class and the average of the experiment class is $29,83 \%$. The highest score of student test results in the control class is in the application aspect of the subject concept whereas the lowest value of aspect obtained in the control class based on the test result is on the interpretation aspect of the data with the detail value of $34.50 \%$. The average value of the three experimental classes has a high enough aspect of the science-process skill, the highest score of science process skill in the experimental class is in the aspect of experimental experiments experiment with value of $87,55 \%$, while the lowest score of skill in the experimental class there is in data communication aspect with percentage value equal to $75,50 \%$, but all aspects of experiment class have high value range that is more than $70 \%$ (> $70 \%)$.

\subsection{Discussion}

Improved learning that can be seen in the control class and the three experimental classes is assessed by three instruments that can generally assess the eleven aspects of the science process skills known so far. In the process of control learning which is a conventional learning, learning practicum given by lecturers, as usual, the teacher has prepared all the things needed by students ranging from practicum tools, practicum materials, work procedures 
to literature or information that may be required by students to support the lab will be done so that students tend to be passive with the process of proving the results of lab work with literature information obtained. The other three classes of classes $\mathrm{A}, \mathrm{B}$, and $\mathrm{C}$ which is experimental learning classes are conducted in a different way than the control classes described earlier. The experimental class on learning practicum of DNA isolation is only given the practicum tools, practicum materials, and working procedures that should be given to avoid mistakes in the experiment but this experiment class is not given any literature or learning resources to support the learning of the practicum. At the beginning of the experimental class, experiments have been making questions related to the lab that will be done so that in general experimental classroom learning with inquiry method looks more interesting than the control class. According to the results of the inquiry learning observation sheets can improve students' ability in making essential questions, because according to (Bruce, Marsha, \& Emily, 2000) that the inquiry self-based model is a process of training students to investigate and explain unusual phenomena, so some questions will appear before the practicum and it is guided by the student. these questions arise from a phenomenon that exists because inquiry learning is designed in such a way that students directly perform the scientific process through the stages of scientific method and practice in a short time [7],[8]. Inquiry learning is also closely related to the improvement of science process skills Because the inquiry learning model is guided by (Wulaningsih, Prayitno, \& Probosari, 2012) able to develop students' science process skills in high academic ability, moderate, low and can involve student activeness in biology learning process [9]. Inquiry study also contains a syntax that is also very suitable if we want to see the students 'science process skills according to (Özdilek \& Bulunuz, 2009) inquiry learning can improve students' science process skills because the inquiry learning procedure is done by involving students in the investigation, helping students identify the concept or methods, and encourage students to find ways to solve problems, teachers play a role in problem-solving and guiding problem-solving activities [10],[11]. In addition, the results of the tests also show that inquiry learning can also enhance the conceptual understanding for students, with inquiry methods of increasing the students' cognitive learning achievement can be understood because the guided inquiry learning model focuses on thinking processes that build their own understanding based on experiences they know. The experiences that students get with teacher guidance at the stages: problem formulation, hypotheses, designing experiments, experiments, presentations make conclusions and give them reinforcement and reflection at the end of learning [12].

\section{Conclusions}

Based on the result of the research, it can be concluded that the application of inquiry method can improve the aspects of science process skill of students in DNA isolation. Eleven aspects of the measured science process skills show significant improvement during the inquiry learning process, whichcan be identified from experimental group's higher score (29.83\%)at the end of the practicum lesson compared to the control group.

\section{References}

[1]M. B. Eko, "Pembelajaran Bioetika Sebagai Pengawal Perkembangan Biologi Modern Dan Penyelamatan Lingkungan Hidup," vol. 3, no. 1, pp. 35-40, 2012.

[2]S. Hariyadi, "Evaluasi akademik mahasiswa biologi terhadap perkuliahan genetika di universitas jember," J. Bioedukasi, vol. 3, no. 2, pp. 336-348, 2015. 
[3]S. Ranjan, G. Kishore, V. S. Jadon, J. P. Bhatt, and S. Gupta, "Standardization of extraction of genomic DNA and PCR-RFLP conditions of Allium stracheyi : A high altitude plant," Ratio, vol. 2, no. 7, pp. 11-14, 2010.

[4]N. Rustaman, Strategi Belajar Mengajar. Malang: UM Press, 2005.

[5]Darmawati, A. Prenti, and E. Srifatmini, "Peningkatan Pembelajaran Genetika dan Evolusi Melalui Model Pembelajaran Problem Based Learning (PBL) Pada Mahasiswa Biologi FKIP UNRI," Pilar Sains, vol. 11, no. 1, pp. 29-37, 2011.

[6]Lansing M. Prescott, J. P. Harley, and Donald A. Klein, Microbiology, 6th ed. USA: McGraw-Hill Higher Education, 2005.

[7]J. R. Bruce, W. Marsha, and C. Emily, Models of Teaching. Newyork: A Person Education Company, 2000.

[8]P. Brickman and C. Gormally, "Effects of inquiry-based learning on students' science literacy skills and confidence," Int. J. Scholarsh. Teach. Learn., vol. 3, no. 2, 2009.

[9]S. Wulaningsih, B. A. Prayitno, and R. M. Probosari, "Pengaruh Model Pembelajaran Inkuiri Terbimbing Terhadap Keterampilan Proses Sains Ditinjau Dari Kemampuan Akademik Siswa Science Process Skills Viewed From Student 'S Academic," Pendidik. Biol., vol. 4, no. 2, pp. 33-43, 2012.

[10]Z. Özdilek and N. Bulunuz, "The effect of a guided inquiry method on pre-service teachers' science teaching self-efficacy beliefs," J. Turkish Sci. Educ., vol. 6, no. 2, pp. 24-42, 2009.

[11]S. Amri and A. K. Iip, Kontruksi Pengembangan Pembelajaran. Jakarta: Prestasi Pustakaraya, 2010.

[12]C. A. Gordon, "The Culture of Inquiry in School Libraries," Sch. Libr. Worldw., vol. 16, no. 1, pp. 73-88, 2010. 